\title{
Low-protein diet prevents tissue lipoprotein lipase activity increase in growing rats
}

\author{
A. Boualga ${ }^{1}$, M. Bouchenak ${ }^{1}$ and J. Belleville ${ }^{2 *}$ \\ ${ }^{1}$ Laboratoire de Physiologie Animale et de la Nutrition, Faculté des Sciences, Université d'Oran, Es-Sénia, 31 000 Oran, \\ Algeria \\ ${ }^{2}$ Unité de Nutrition Cellulaire et Métabolique, Faculté des Sciences Mirande, Université de Bourgogne, BP 400, 21011 Dijon \\ Cedex, France
}

(Received 23 April 1999 - Revised 16 February 2000 - Accepted 20 March 2000)

\begin{abstract}
The time course of changes in tissue lipolytic activities was studied in young rats during the consumption of a low-protein diet containing $50 \mathrm{~g}$ protein $/ \mathrm{kg}$ ( $40 \mathrm{~g}$ wheat gluten $+10 \mathrm{~g}$ casein/ $\mathrm{kg}$ ) for $28 \mathrm{~d}$ followed by balanced refeeding with $200 \mathrm{~g}$ protein $/ \mathrm{kg}$ ( $160 \mathrm{~g}$ wheat gluten $+40 \mathrm{~g}$ casein $/ \mathrm{kg}$ ) for $28 \mathrm{~d}$. Lipoprotein lipase (LPL) activities were compared with the values of a control group fed a balanced diet containing $200 \mathrm{~g}$ protein $/ \mathrm{kg}$ for $56 \mathrm{~d}$. At the end of protein malnutrition period, the epididymal fat tissue LPL activity represented $36 \%$, and that of heart and gastrocnemius was $44 \%$, of those of the control group. These differences were accompanied by lower serum- and VLDL-triacylglycerols (TAG), respectively $47.6 \%$ and 31 $\%$ of the control group values, probably resulting from reduced synthesis of VLDL-apolipoproteins (29\% of control group values), concomitant with liver lipid accumulation (4.8-fold) and little lipid storage in epididymal fat tissue. At day 2 of refeeding, there was no significant difference in liver and epididymal fat tissue LPL activities between experimental and control rats. At the end of the refeeding period, LPL activity of epididymal fat and liver lipolytic activity had increased and became similar to control group values. The consumption of a low-protein diet prevented the increase in extrahepatic LPL activities as observed in the control group. The alterations in LPL activity suggest that a low-protein diet limits lipid storage in adipose tissue due to reduced serum VLDL-TAG availability.
\end{abstract}

Lipoprotein lipase: Protein malnutrition: Balanced refeeding: Rat

Hepatic triacylglycerol (TAG) lipase (TAG acyl hydrolase) and lipoprotein lipase (TAG-protein acyl hydrolase) catalyse the hydrolysis of plasma lipoprotein TAG. They play key roles in vascular lipoprotein metabolism through an efficient transfer of energy in the form of lipids from the sites of synthesis to those of storage or utilisation. The major tissues in which lipoprotein lipase (LPL) activity has been found include adipose tissue, heart, muscles and several other tissues (Soteriou \& Cryer, 1993). LPL, present at the luminal surface of the capillary endothelium, is synthesised predominantly by parenchymal cells and requires, for maximal activity, apolipoprotein (Apo) C-II, an activating cofactor which is found in plasma associated mainly with chylomicrons, VLDL and HDL (Goldberg et al. 1990; Ikeda et al. 1989). The substrates for LPL are chylomicrons and VLDL which, by hydrolysis, turn into smaller remnants and are rapidly cleared from the blood stream. Although LPL is considered an essentially extrahepatic enzyme, substantial LPL activity can also be found in the liver. In contrast to LPL, hepatic lipase (HL), which is almost exclusive to hepatic sinusoids, does not require ApoC-II as activator (Olivecrona \& Bengtsson-Olivecrona, 1990). HL, i.e. TAG hydrolase of hepatic extract differed from LPL in that it was insensitive to Apo cofactor and was not inhibited by preincubation with a high concentration of $\mathrm{NaCl}$ or protamine sulfate. Although the physiological function of HL has not been clearly defined, there is increasing evidence that it also acts as a phospholipase (Kuusi et al. 1979a). HL and LPL localisations facilitate the cellular uptake of lipolytic products (free fatty acids and monoacylglycerols) (Brunzell, 1989; Eckel, 1989) available to the adjacent cells for oxidation or resynthesis into TAG for storage.

HL and LPL have been largely investigated during

\footnotetext{
Abbreviations: Apo, apolipoprotein; HL, hepatic lipase; LPL, lipoprotein lipase; TAG, triacylglycerol.

* Corresponding author: Dr J. Belleville, fax +33 3803963 30, email jbellev@u-bourgogne.fr
} 
starvation followed by refeeding, and during the consumption of a low-energy diet, but not during protein malnutrition followed by balanced refeeding. Protein malnutrition involves a low level of circulating TAG, due to a significant VLDL diminution in young rats (Flores et al. 1970a) and infants (Truswell et al. 1969; Flores et al. 1970b; Waterlow, 1975). The origin of this low plasma VLDL level is a decrease in VLDL-Apo synthesis in both kwashiorkor patients (Seakins \& Waterlow, 1972) and protein-depleted rats (Meghelli-Bouchenak et al. 1987, 1989a,b). Moreover, in protein-depleted rats, Agbedana (1980) showed that LPL activity is significantly reduced in adipose tissue, whereas there are no significant changes in heart and liver lipolytic activities. In a previous study, we have shown that total plasma lipolytic activity, which represents HL and LPL activities, remains low and stable in rats throughout the period of protein malnutrition (Lamri et al. 1995). We have also observed that VLDL composition varies significantly with the type of protein malnutrition (50 g wheat gluten or $20 \mathrm{~g}$ casein $/ \mathrm{kg}$ ). These modifications could be attributable to the various low levels of plasma VLDL-ApoC-II in rats fed protein-depleted diets, which may modify their activating effect on LPL activity.

The aim of the present study was to determine whether liver total lipolytic activity, namely HL and LPL activity in epididymal fat, gastrocnemius muscle and heart, were important in determining fatty acid availability to tissues during the consumption of a low-protein diet $(40 \mathrm{~g}$ gluten $+10 \mathrm{~g}$ casein $/ \mathrm{kg}$ ) followed by balanced refeeding in young rats. Moreover, the amount of TAG in liver and serum VLDL were investigated in order to see the organ capacity for release of free fatty acids from this substrate. We have chosen this protein composition because in numerous developing countries, particularly in Algeria, proteins originate mainly from cereals and to a lesser extent from dairy products. Since gluten, the main cereal protein, has a low lysine level, casein was added to the gluten diets, thus increasing their lysine level and therefore remedying their deficiency.

\section{Material and methods}

\section{Animals and diets}

Male Wistar rats ( $n$ 72) at weaning (Iffa Credo, l'Arbresle, Lyon, France) weighing 40 (SE 5) $\mathrm{g}$ at the beginning of the experiment were allowed free access to a balanced diet containing $200 \mathrm{~g}$ protein $(160 \mathrm{~g}$ gluten $+40 \mathrm{~g}$ casein $/ \mathrm{kg}$ ) for $5 \mathrm{~d}$. After this adaptation period, they weighed 60 (SE 5) g and were then randomised into equal groups. A control group was fed the same balanced diet for $56 \mathrm{~d}$. The experimental group was fed a low-protein diet containing $50 \mathrm{~g}$ protein $(40 \mathrm{~g}$ gluten $+10 \mathrm{~g}$ casein $/ \mathrm{kg}$ ) for $28 \mathrm{~d}$ (protein malnutrition period) and then the balanced diet for $28 \mathrm{~d}$ (balanced refeeding period). Table 1 shows the weight and energetic compositions of both diets which were isoenergetic. In the low-protein diet, the loss of energy from protein was compensated for by corn starch.

Rats were kept in wire-bottomed cages under an automatic lighting schedule (lights on 07.00 to 19.00 hours), at constant temperature $\left(24^{\circ} \mathrm{C}\right)$ and humidity $(60$
Table 1. Diet composition*

\begin{tabular}{|c|c|c|}
\hline Ingredients & $\begin{array}{l}40 \mathrm{~g} \text { Casein+160 g } \\
\text { gluten } / \mathrm{kg}(\mathrm{g} / \mathrm{kg} \text { diet })\end{array}$ & $\begin{array}{l}10 \mathrm{~g} \text { Casein+40 g } \\
\text { gluten } / \mathrm{kg}(\mathrm{g} / \mathrm{kg} \text { diet) }\end{array}$ \\
\hline Milk casein $^{\dagger}$ & 40 & 10 \\
\hline Wheat gluten ${ }^{\ddagger}$ & 160 & 40 \\
\hline Corn starch ${ }^{\ddagger}$ & 512 & 638 \\
\hline Sucrose $e^{\S}$ & 98 & 122 \\
\hline Sunflower oil ${ }^{\S}$ & 80 & 80 \\
\hline Cellulose $^{\ddagger}$ & 50 & 50 \\
\hline Mineral mix" & 40 & 40 \\
\hline Vitamin mix $^{\text {q }}$ & 20 & 20 \\
\hline
\end{tabular}

* Diets were isoenergetic $(1657 \mathrm{~kJ} / \mathrm{kg})$ and were given in powdered form.

† Merck, Darmstadt, Germany.

¥ UAR; Villemoisson 91360, Epinay S/Orge, France.

$\S$ Commercial Products, Oran, Algeria.

|| UAR 205 B; Villemoisson, Epinay S/Orge, France. Mineral mix provided (g/ $\mathrm{kg}$ diet): $\mathrm{Ca} 4, \mathrm{~K} 2.4, \mathrm{Na} 1.6, \mathrm{Mg} 0.4, \mathrm{Fe} \mathrm{0.12,} \mathrm{Mn} \mathrm{0.032,} \mathrm{Cu} \mathrm{0.005,} \mathrm{Zn} \mathrm{0.018,}$ Co $0.00004, I 0.00002$

I UAR 200; Villemoisson, Epinay S/Orge, France. Vitamin mix provided (mg/ $\mathrm{kg}$ diet): thiamin 40 , riboflavin 30 , nicotinic acid 140 , pyridoxine 20 , pyridoxal 300 , cyanocobalamin $0 \cdot 1$, ascorbic acid 1600, $\alpha$-tocopherol 340 , menadione 80 , calcium panthotenate 200 , choline 2720 , pteroylmonoglutaric acid $10, p$ aminobenzoic acid 100, biotin 0.6 , retinol 12 , cholecalciferol 0.125 .

$\%)$. Diets and water were freely available. We followed the general guidelines of the Council of European Communities (1986) for the care and use of laboratory animals. The body weight and food intake were measured daily from days 1 to 7 of protein malnutrition (period 1) and balanced refeeding (period 3) and from days 22 to 28 of protein malnutrition (period 2) and refeeding (period 4).

\section{Substrate preparation for the lipolytic activities}

The substrate emulsion was prepared according to the method of Okabe et al. (1984): $250 \mathrm{mg}$ unlabelled triolein (Prolabo, Paris, France) were mixed with $0.185 \mathrm{MBq}$ glycerol tri $\left(9-10(n)-{ }^{3} \mathrm{H}\right)$ oleate (NET 431 NEN, Boston, MA, USA). After organic solvant removal under $\mathrm{N}_{2}$ stream, the mixture was sonicated with $4 \mathrm{~g}$ bovine serum albumin fraction V/l (Merck, Darmstadt, Germany), $2 \mathrm{ml}$ Triton $\mathrm{X} 100(10 \mathrm{ml} / \mathrm{l})$ and $20 \mathrm{ml} 0 \cdot 2 \mathrm{M}$-Tris-HCl buffer (pH 8.6).

\section{Tissue preparation for lipoprotein lipase activity determination}

At days 2, 14 and 28 of protein malnutrition and days 2, 14 and 28 of balanced refeeding, after an overnight fast, six rats from each group were bled from the abdominal aorta under anaesthesia $(60 \mathrm{mg}$ sodium pentobarbital $/ \mathrm{kg}$ body weight). Epididymal fat, heart, gastrocnemius muscle and liver were quickly excised and samples for enzyme activity analysis obtained by extraction with acetone and diethyl ethyl; these samples, which account for both the extracellular and the inactive intracellular LPL compartments, were used as the defatted preparation for measuring total lipolytic activity, according to the method of Hamosh et al. (1970): $200 \mathrm{mg}$ of each tissue were washed in cold $0 \cdot 15 \mathrm{M}-\mathrm{NaCl}$ to remove traces of blood and were homogenised in $8 \mathrm{ml}$ cold acetone. The insoluble tissue constituents in acetone were collected after filtration through Whatman paper no. 5 on a Buchner funnel. The tissue residue was washed three times with 
cold diethyl ether. The defatted preparation was dried, scraped off the filter paper and solubilised in cold $0.2 \mathrm{M}-$ Tris-HCl buffer ( $\mathrm{pH} 8.6$ ) containing $1000 \mathrm{U}$ heparin/l. The residue was removed from each extract by centrifugation of $4^{\circ} \mathrm{C}$ for $20 \mathrm{~min}$. The supernatant was used as the sample for enzyme activity analysis.

\section{Enzyme assay}

Lipolytic activities in samples, prepared as described earlier, were measured by the release of labelled oleic acid from 9-10 $(n)^{3} \mathrm{H}$-triolein with bovine serum albumin as fatty acid acceptor. The sample $(5 \mathrm{ml})$ was incubated with $0.5 \mathrm{ml}$ substrate emulsion containing heat-inactivated pooled serum $(50 \mathrm{ml} / \mathrm{l})$ as ApoC-II source. The serum was prepared from rat blood inactivated at $56^{\circ} \mathrm{C}$ for $45 \mathrm{~min}$. After $1 \mathrm{~h}$ at $37^{\circ} \mathrm{C}$, the incubation was stopped by the addition of $4 \mathrm{ml}$ methanol. The heat-inactivated pooled serum used in the assay contained a negligible amount of TAG $(0.09 \mathrm{mg})$ compared with triolein $(6.5 \mathrm{mg})$ and its contribution $(1 \%)$ was a negligible dilution source of the specific activity. ApoC-II from the plasma $(0.5 \mathrm{ml})$ in the assay was sufficient for maximal activating effect on lipolytic activity.

\section{Lipid extraction}

Lipid extraction on incubation was performed by the method of Folch et al. (1957). Total lipids were separated by TLC with hexane-diethyl ether-acetic acid (70:30:1, by vol.) as eluant. The different lipids were revealed by plate exposure to I vapours and directly scraped into scintillation vials containing $10 \mathrm{ml}$ Ready solv HP (Beckman, Palo Alto, CA, USA) as scintillant. The samples were counted in Beckman LS 7500 scintillation counter (Beckman Instruments, Palo Alto, CA, USA). Total release of free fatty acids was calculated according to the method of Hills \& Mukherjee (1988): (radioactivity (Bq) at origin/(radioactivity $(\mathrm{Bq})$ at origin+radioactivity $(\mathrm{Bq})$ in remainder $) \times$ TAG $(\mu \mathrm{mol})$ in assay $\times 3$, and was expressed as $\mu \mathrm{mol} / \mathrm{h}$ per $\mathrm{g}$ fresh tissue.

\section{VLDL isolation}

The technique used has been detailed in a previous paper (Meghelli-Bouchenak et al. 1991). Serum samples (2 ml) were overlaid with $4 \mathrm{ml} 0 \cdot 15 \mathrm{M}-\mathrm{NaCl}$ and $0 \cdot 001 \mathrm{M}-\mathrm{Na}_{2}$ EDTA (density $1.006 \mathrm{~kg} / \mathrm{l}$ ). After centrifugation at $15^{\circ} \mathrm{C}$ for $17 \mathrm{~h}$ at $108000 \mathrm{~g}$ in a Beckman L8-55 Ultracentrifuge equipped with a $50 \mathrm{Ti}$ rotor (Beckman Instruments), floating VLDL were isolated. VLDL fractions were subjected to partial lyophylisation, followed by rapid delipidation with cold diethyl ether at $4{ }^{\circ} \mathrm{C}$ in order to avoid the precipitation of high molecular mass Apo.

\section{Chemical analysis}

The total lipids in the liver were extracted according to the method of Folch et al. (1957). An aliquot of liver total lipid, serum- and VLDL-TAG were determined by the enzymatic method using glycerol as standard (Boehringer, Mannheim,
Germany). Protein contents of VLDL were measured by the method of Lowry et al. (1951) using bovine serum albumin (Sigma, L'Isle d'Abeau, France) as standard.

\section{Statistical analysis}

Values are means with their standard errors. Statistical evaluation of the data was carried out using Statistica (version 4.1, Statsoft, Inc., 1994; Paris, France). Data were tested by two-way ANOVA and classification of the means was performed using Duncan's multiple range test (1955): (1) between both groups at each sampling time; (2) in the same group at different times during protein malnutrition and balanced refeeding. Linear regression analysis was used to determine the coefficients of correlation between some serum indices and liver steatosis. Statistical significance was accepted at $P<0 \cdot 05$.

\section{Results}

\section{Body weight and food intake}

After $28 \mathrm{~d}$ protein malnutrition, the body weights of the experimental rats was only $40 \%$ of those of control rats (Fig. 1). Balanced refeeding promoted a rapid weight increase in the experimental group, but at day 28 of balanced refeeding, their weights were only $70 \%$ of those of the control rats. The daily food intake per rat (Table 2) was similar, except at the end of malnutrition (period 2) and at the beginning of refeeding (period 3) when the values in the experimental group represented $50 \%$ and $55 \%$

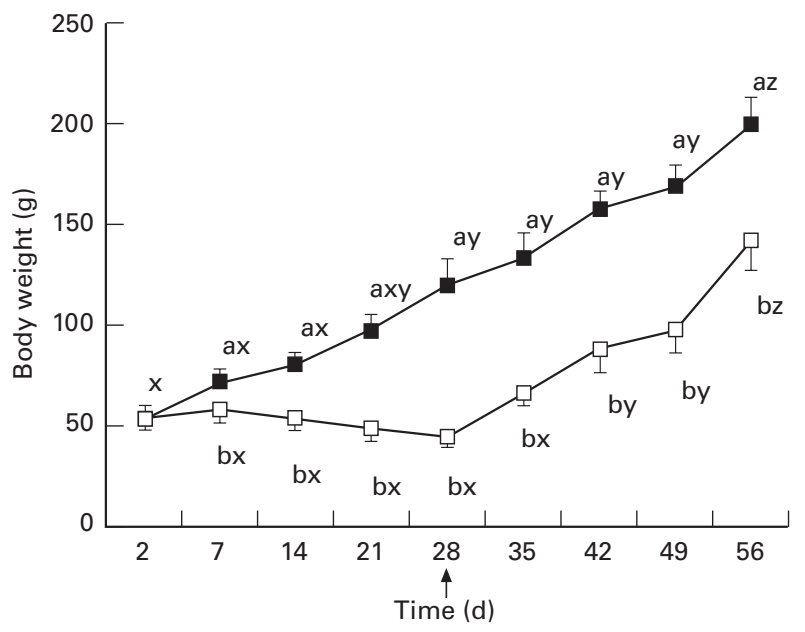

Fig. 1. Rat body weights during the consumption of the low-protein diet followed by refeeding the balanced diet. Values are means for six rats per group with their standard errors shown by vertical bars. The control group (-口-) was fed the balanced diet $(160 \mathrm{~g}$ wheat gluten $+40 \mathrm{~g}$ casein $/ \mathrm{kg}$ ) for $56 \mathrm{~d}$. The experimental group (- $\square-)$ was fed the low-protein diet $(40 \mathrm{~g}$ wheat gluten $+10 \mathrm{~g}$ casein $/ \mathrm{kg}$ ) for $28 \mathrm{~d}$ (protein malnutrition) then was refed the balanced diet for $28 \mathrm{~d}$ (balanced refeeding). $\uparrow$, Change of diet. For details of composition of diets see Table 1. ${ }^{a, b}$ Mean values were significantly different from those of the control group (two-way ANOVA and Duncan's multiple range test): $P<0.05 .{ }^{\mathrm{x}, \mathrm{y}, \mathrm{z}}$ Mean values were significantly different within a group over time (two-way ANOVA and Duncan's multiple range test): $P<0.05$. 
Table 2. Food and energy intakes of rats during protein malnutrition followed by balanced refeeding* (Mean values with their standard errors for six rats per group)

\begin{tabular}{|c|c|c|c|c|c|c|c|c|}
\hline & \multicolumn{4}{|c|}{ Protein malnutrition } & \multicolumn{4}{|c|}{ Balanced refeeding } \\
\hline & \multicolumn{2}{|c|}{ Period 1 (days 1-7) } & \multicolumn{2}{|c|}{ Period 2 (days 22-28) } & \multicolumn{2}{|c|}{ Period 3 (days 1-7) } & \multicolumn{2}{|c|}{ Period 4 (days 22-28) } \\
\hline & Mean & SE & Mean & SE & Mean & SE & Mean & SE \\
\hline \multicolumn{9}{|l|}{ Food intake ( $\mathrm{g} / \mathrm{d}$ per rat) } \\
\hline Control group & $5 \cdot 44^{\mathrm{x}}$ & 0.77 & $6 \cdot 68^{\mathrm{axy}}$ & 1.02 & $7 \cdot 87^{\text {ay }}$ & 0.56 & $4 \cdot 31^{x}$ & 0.94 \\
\hline Experimental group & $4 \cdot 61$ & 0.89 & $3 \cdot 37^{\mathrm{b}}$ & 0.91 & $5 \cdot 30^{\mathrm{b}}$ & 0.43 & $4 \cdot 34$ & 0.79 \\
\hline \multicolumn{9}{|c|}{ Food intake (g/d per $100 \mathrm{~g} \mathrm{BW)}$} \\
\hline Control group & $9 \cdot 91^{x}$ & 0.45 & $6 \cdot 68^{\mathrm{y}}$ & 0.55 & $6 \cdot 56^{\text {by }}$ & 0.81 & $2 \cdot 06^{z}$ & 0.36 \\
\hline Experimental group & $9 \cdot 58^{x}$ & 2.05 & $7 \cdot 18^{\mathrm{x}}$ & $2 \cdot 64$ & $9 \cdot 57^{\mathrm{ax}}$ & 0.42 & $3 \cdot 17^{y}$ & 0.61 \\
\hline \multicolumn{9}{|c|}{ Energy intake $\left(\mathrm{kJ} / \mathrm{d}\right.$ per $\left.\mathrm{W}^{0.75}\right)$} \\
\hline Control group & $813 \cdot 21^{x}$ & $40 \cdot 66$ & $628 \cdot 90^{y}$ & $54 \cdot 70$ & $655 \cdot 43^{y}$ & $44 \cdot 50$ & $236 \cdot 58^{z}$ & $37 \cdot 44$ \\
\hline Experimental group & $756 \cdot 12^{x}$ & $170 \cdot 20$ & $572 \cdot 62^{x}$ & $110 \cdot 70$ & $753 \cdot 27^{x}$ & $37 \cdot 21$ & $327 \cdot 25^{y}$ & $50 \cdot 20$ \\
\hline
\end{tabular}

BW, body weight; $\mathrm{W}^{0.75}$; metabolic body weight.

a,b Mean values within a column with unlike superscript letters were significantly different (two-way ANOVA and Duncan's multiple range test; $P<0.05$ ).

$\mathrm{x}, \mathrm{y}, \mathrm{z}$ Mean values within a row with unlike superscript letters were significantly different (two-way ANOVA and Duncan's multiple range test; $P<0.05$ ).

* The control group were fed the balanced diet $(160 \mathrm{~g}$ wheat gluten $+40 \mathrm{~g}$ casein $/ \mathrm{kg})$ for $56 \mathrm{~d}$. The experimental group were fed the low-protein diet $(40 \mathrm{~g}$ wheat gluten $+10 \mathrm{~g}$ casein $/ \mathrm{kg}$ ) for $28 \mathrm{~d}$ (protein malnutrition) then refed the balanced diet for $28 \mathrm{~d}$ (balanced refeeding). For details of composition of diets see Table 1 .

respectively of those of control rats. However, the metabolisable energy intake calculated factorially from food consumption and expressed as $\mathrm{kJ} / \mathrm{d}$ per $\mathrm{kg}$ metabolic body weight $\left(\mathrm{W}^{0.75}\right)$ was similar in both groups at each period, but the values were only $30 \%$ and $43 \%$ in the control and experimental groups respectively at the end of the study (period 4) compared with the values obtained at the beginning of the experiment (period 1).

\section{Relative weights of tissues}

Changes in tissue weights are expressed as a percentage of body weight (Fig. 2). During protein malnutrition, gastrocnemius, heart and liver relative weights in protein-depleted rats were not significantly different from those of the control rats. In contrast, at day 14 of protein malnutrition, the relative weight of epididymal fat was significantly lower than that of the control group. At day 28 of protein malnutrition, it represented only $30 \%$ of the control values. At day 2 of refeeding, only relative weight of the heart was increased and became significantly higher in the experimental group than that of the control group, whereas that of epididymal fat remained significantly lower.

\section{Lipoprotein lipase activity of tissues}

In the control group, the highest LPL activities per $g$ fresh tissue were found in epididymal fat, whereas the lowest lipolytic values were obtained in the liver (Fig. 3). At day 2 of protein malnutrition, only liver lipolytic activity of the experimental group was significantly higher than that of the control group. At day 14 of protein malnutrition, LPL activities of epididymal fat and heart were significantly reduced. At the end of protein malnutrition, epididymal fat LPL activity was reduced to $33.4 \mu \mathrm{mol}$ free fatty acids released/h per $\mathrm{g}$ tissue which represented only $30 \%$ of the control value (102.4 $\mu \mathrm{mol}$ free fatty acids released/h per $\mathrm{g}$ ). Gastrocnemius and heart LPL activities were less impaired, with 6.8 and $5.6 \mu \mathrm{mol}$ free fatty acids released/h per $\mathrm{g}$ respectively which represented $44 \%$ of control values. At day 2 of balanced refeeding, LPL activities were increased and became similar in epididymal fat and even greater in the liver of the experimental group compared with those of control rats. However, in these tissues lipolytic activities decreased at day 14 of refeeding. At the beginning of refeeding, only heart and gastrocnemius lipolytic activities remained lower than control values. At the end of refeeding, LPL activities of epididymal fat and liver increased and became similar to control values. Gastrocnemius and heart LPL activities increased progressively during balanced refeeding; however, only heart LPL activity was still significantly lower in the experimental group.

\section{Liver triacylglycerol content and serum VLDL- apolipoprotein and-triacylglycerol concentrations}

At the beginning of the experiment (day 0), the hepatic TAG values were about $9.02 \mu \mathrm{mol} / \mathrm{g}$ liver. In the experimental group, a progressively greater liver TAG concentration was noted which was particularly high at day 28 of protein malnutrition when the values were $4 \cdot 86$-fold higher, whereas serum TAG amounts were $2 \cdot 10$-fold lower, than those of the control group (Table 3). Moreover, values for VLDL-TAG and Apo progressively decreased from day 2 to day 28 of protein malnutrition when the values were $3 \cdot 21$ and $3 \cdot 37$-fold lower in the experimental group than in the control group respectively. In the experimental group during protein malnutrition, there was a significant negative correlation between VLDL-Apo and liver TAG content $(r-0.89, P<0.01)$ on the one hand, and between VLDL- and liver TAG content $(r-0.88, P<0 \cdot 01)$ on the other hand. During balanced refeeding, the same inverse relationship was observed between VLDL-Apo, VLDLTAG content and hepatic steatosis $(r-0.93, P<0.01)$.

\section{Discussion}

In the present experiment, we chose not to use pair-fed controls for the depleted rats because the rats that consumed low-protein diets ate less and their body weights were lower, but on a body weight basis, the energy intake was the same. Therefore, we are essentially dealing with 

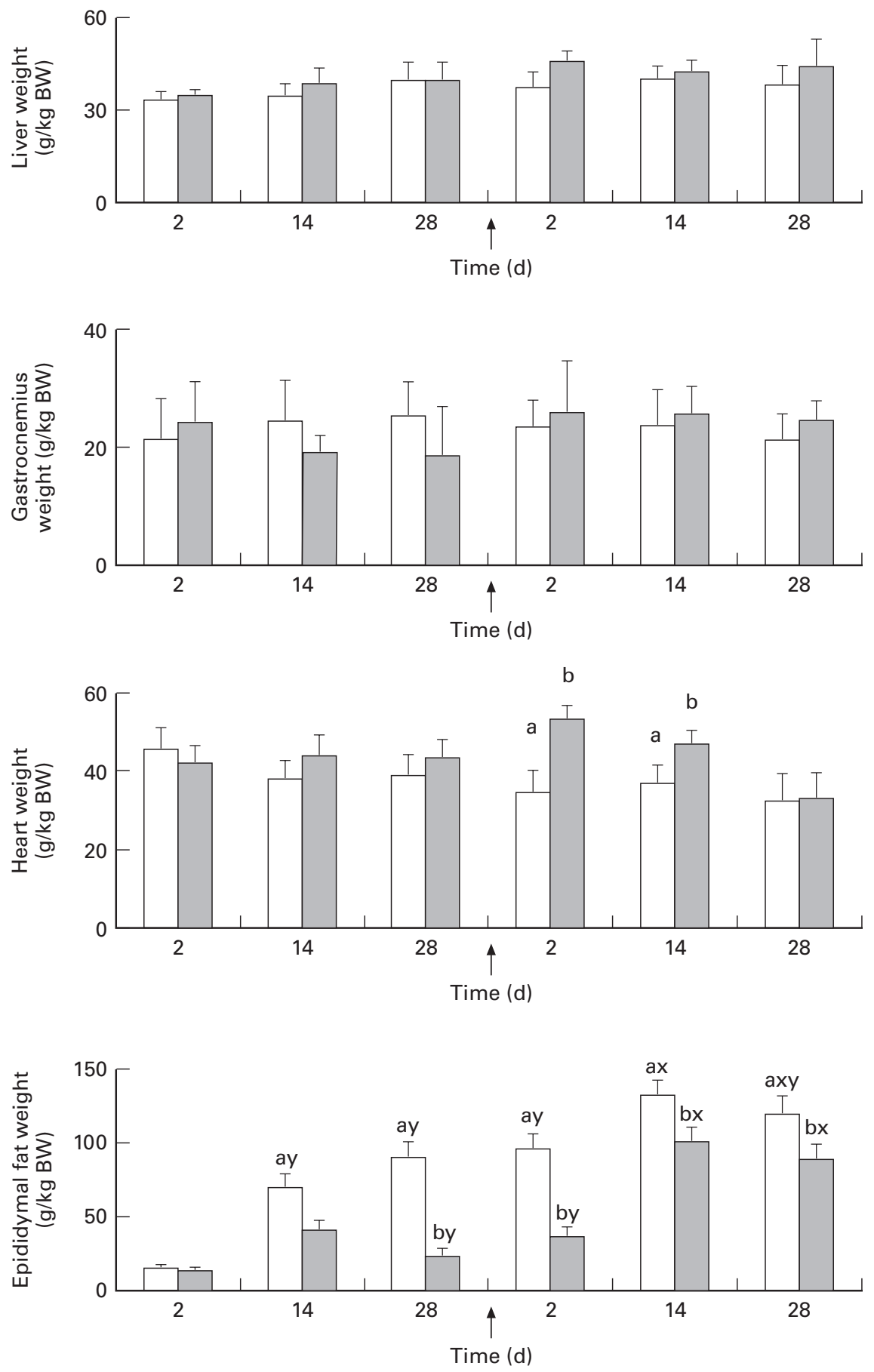

Fig. 2. Relative weights of liver, gastrocnemius, heart and epididymal fat (expressed as g tissue/kg body weight (BW). Values are means for six rats per group with their standard errors shown by vertical bars. The control group ( $\square$ ) was fed the balanced diet $(160 \mathrm{~g}$ wheat gluten $+40 \mathrm{~g}$ casein/ $\mathrm{kg}$ ) for $56 \mathrm{~d}$. The experimental group (㖥) was fed the low-protein diet $(40 \mathrm{~g}$ wheat gluten $+10 \mathrm{~g}$ casein $/ \mathrm{kg}$ ) for $28 \mathrm{~d}$ (protein malnutrition) then was refed the balanced diet for $28 \mathrm{~d}$ (balanced refeeding). $\uparrow$, Change of diet. For details of the composition of diets see Table 1. ${ }^{\text {a,b }}$ Mean values were significantly different from those of the control group (two-way ANOVA and Duncan's multiple range test): $P<0.05{ }^{x, y, z}$ Mean values were significantly different within a group over time (twoway ANOVA and Duncan's multiple range test): $P<0.05$.

protein malnutrition. In addition, the two specific symptoms of protein malnutrition, i.e. liver steatosis and oedema, were observed with a similar experimental protocol in a previous study (Meghelli-Bouchenak et al. 1989b).
The protein-depleted diet $(40 \mathrm{~g}$ gluten $+10 \mathrm{~g}$ casein $/ \mathrm{kg})$ immediately stopped rat growth (Fig. 1), whereas the control rat weights were enhanced with age. It was therefore necessary to compare the experimental group 

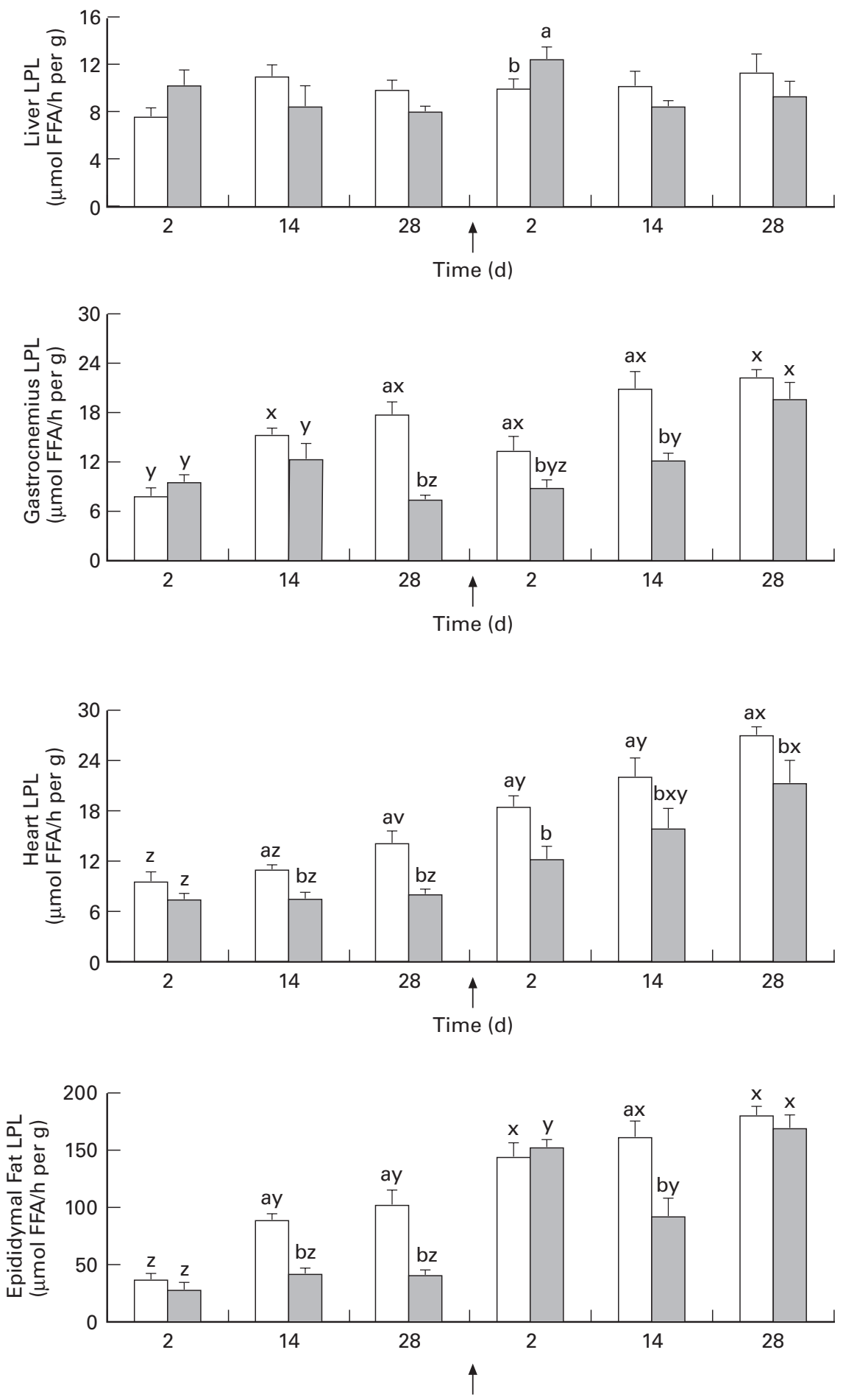

Time (d)

Fig. 3. Lipoprotein-lipase (LPL) activities of liver, gastrocnemius, heart and epididymal fat (expressed in $\mu \mathrm{mol}$ free fatty acids released/h per $\mathrm{g}$ fresh tissue). Values are means for six rats per group with their standard errors shown by vertical bars. The control group ( $\square$ ) was fed the balanced diet (160 g wheat gluten $+40 \mathrm{~g}$ casein $/ \mathrm{kg}$ ) for $56 \mathrm{~d}$. The experimental group (國) was fed the low-protein diet $(40 \mathrm{~g}$ wheat gluten $+10 \mathrm{~g}$ casein $/ \mathrm{kg}$ ) for $28 \mathrm{~d}$ (protein malnutrition) then was refed the balanced diet for $28 \mathrm{~d}$ (balanced refeeding). $\uparrow$, Change of diet. For details of composition of diets see Table 1. ${ }^{a, b}$ Mean values were significantly different from those of the control group (two-way ANOVA and Duncan's multiple range test): $P<0 \cdot 05 .{ }^{\mathrm{x}, \mathrm{y}, \mathrm{z}}$ Mean values were significantly different within a group over time (two-way ANOVA and Duncan's multiple range test): $P<0.05$ $x, y, z$ Mean values were significantly different within a group over time (two-way ANOVA and Duncan's multiple range test): $P<0.05$. 
Table 3. Liver, serum and VLDL-triacylglycerol (TAG) and VLDL-apolipoprotein (Apo) concentrations during protein malnutrition followed by balanced refeeding*

(Mean values with their standard errors for six rats per group)

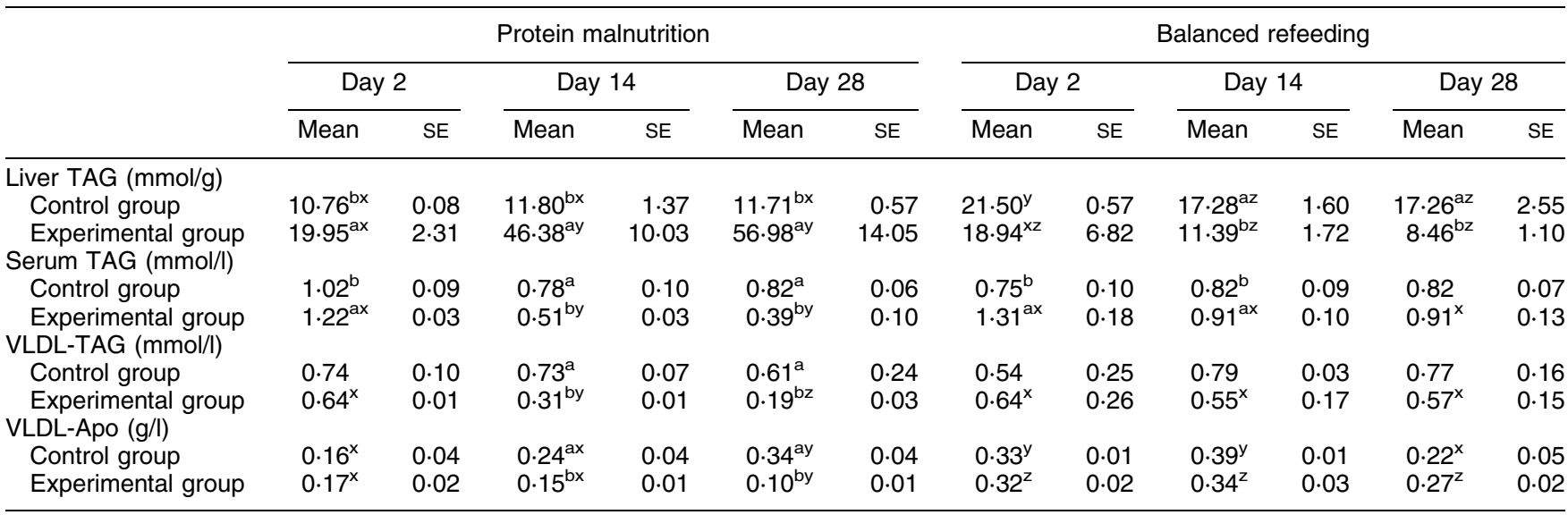

a,b Mean values within a column with unlike superscript letters were significantly different (two-way ANOVA and Duncan's multiple range test; $P<0.05$ ).

$\mathrm{x}, \mathrm{y}, \mathrm{z}$ Mean values within a row with unlike superscript letters were significantly different (two-way ANOVA and Duncan's multiple range test; $P<0.05$ ).

* The control group were fed the balanced diet ( $160 \mathrm{~g}$ wheat gluten $+40 \mathrm{~g}$ casein $/ \mathrm{kg}$ ) for $56 \mathrm{~d}$. The experimental group were fed the low-protein diet (40 g wheat gluten $+10 \mathrm{~g}$ casein $/ \mathrm{kg}$ ) for $28 \mathrm{~d}$ (protein malnutrition) then refed the balanced diet for $28 \mathrm{~d}$ (balanced refeeding). For details of composition of diets see Table 1 .

values with the control values at the same day of the experiment. During balanced refeeding, the body weights of experimental rats increased rapidly and markedly at the beginning, but 28 days of refeeding did not enable them to reach the body weight of the control rats, in spite of a similar food intake. Indeed, Mohamed-Benkada et al. (1993) have shown under similar experimental conditions that total recovery of body weight was obtained only after 3 months of balanced refeeding.

During protein malnutrition, the deficient group maintained constant LPL activity and relative weight of epididymal fat; however, when compared with the control group, these values were significantly decreased from day 14 to day 28 of protein malnutrition. Gastrocnemius and heart LPL activities were also stable during protein malnutrition but showed a reduction at day 28 of protein malnutrition when compared with control values. Only liver lipolytic activity remained unchanged during protein malnutrition. Similarly, Agbedana (1980) showed that adipose tissue LPL in malnourished rats was largely reduced, whereas changes in liver and heart lipolytic activities were not significant. It is suggested that these changes in LPL activities could be part of the mechanism of the development of fatty liver through the relative stability of HL activity which was necessary to TAG hydrolysis but the response to the reduced hepatic output of VLDL was the major part of this mechanism as shown previously (Meghelli-Bouchenak et al. (1989b). Indeed, in our experiment VLDL-Apo values were significantly reduced during protein malnutrition (Table 3) in the experimental group compared with control values. Rat serum lipoproteins did not show the same sensitivity to protein malnutrition. Indeed, in our previous paper (Meghelli-Bouchenak et al. 1989b) LDL and HDL were not affected by protein malnutrition. Moreover, Faergeman et al. (1975) established that most VLDL constituents in the rat are catabolised by the liver and only a small proportion is transferred into the LDL fraction. This has been put forward as the explanation for the small plasma pool size of LDL in the rat compared with man in whom most VLDL are converted to LDL (Fidge \& Poulis, 1978), whereas some studies carried out in children with kwashiorkor have shown a reduced level of these lipoproteins (Onitri \& Boyo, 1975). Kadowaki et al. (1992) have shown that HL is necessary for the hepatic uptake of both HDL-TAG and cholesteryl esters. Moreover, in rats injected with antibody to endothelial HL, HDL-phospholipids and unesterified cholesterol are increased (Kuusi et al. 1979a,b). The unchanged HDL contents in association with the fall in VLDL concentrations during protein malnutrition (Meghelli-Bouchenak et al. 1989a) are surprising because additional Apo (especially ApoC and -E) and lipids are known to be transferred to HDL after hydrolysis of TAG in the core of TAG-rich lipoproteins (chylomicrons and VLDL) by LPL, producing larger HDL (Eisenberg, 1984). The hepatic TAG contents with the $40 \mathrm{~g}$ wheat gluten $+10 \mathrm{~g}$ casein $/ \mathrm{kg}$ diet were $4 \cdot 86$-fold higher than those with $160 \mathrm{~g}$ wheat gluten $+40 \mathrm{~g}$ casein $/ \mathrm{kg}$, in spite of an increase in sucrose feeding $(+24 \mathrm{~g} / \mathrm{kg})$. Liver TAG accumulation with the low-protein diet could have been chiefly due to overall amino-acid deficiency. The highly negative correlations observed between VLDL-Apo and liver TAG contents on the one hand, and the low concentration of VLDL-TAG (3.2-fold lower in the experimental group compared with control group) on the other hand, confirmed that hepatic steatosis was essentially due to impaired exportation and transport of TAG by VLDL. Indeed, there was no hypertriacylglycerolaemia despite the increase in sucrose in the diet. The unchanged hepatic lipolytic activity could participate in TAG accumulation in the liver during protein malnutrition. Moreover, the experimental group consuming more carbohydrates than controls $(+24 \mathrm{~g} / \mathrm{kg})$ developed a fatty liver accompanied by a low concentration of VLDL-TAG.

Stable LPL activities of epididymal fat, gastrocnemius, heart and liver on the one hand, and the reduction in these 
activities when compared with control group values on the other hand, were noted with this type of protein malnutrition. The lower activities were not sufficient to diminish the hydrolysis of the low level of VLDL-TAG, which would explain the low serum and VLDL-TAG concentrations. These data suggest that during protein malnutrition, the low available serum VLDL-TAG was probably sufficient to maintain the relative weight of epididymal fat at the level observed at the beginning of experiment and did not allow its increase, as observed in the control group. This could be explained by the fact that the low-protein diet limited lipid storage in adipose tissue from the low available serum VLDL-TAG, which could favour lipid utilisation by muscle and heart. Indeed, gastrocnemius and heart LPL activities were less reduced than those of epididymal fat in deficient rats and their relative weights remained unchanged during protein malnutrition and balanced refeeding.

In the rat, however, the effects of hypoinsulinaemia relative to protein deficiency (Lunn et al. 1983) on the low levels of LPL activity support the current interest in insulin resistance. It has been reported that fetal undernutrition may induce impaired $\beta$-cell development and insulin resistance (Barker et al. 1993; Barker, 1995). Impaired VLDL catabolism, reduced LPL activity, overproduction of TAG and ApoB-100 are common in adult diabetes mellitus (Ginsberg, 1991). Moreover, adipose tissue lipoprotein lipase activity is regulated by a mechanism involving insulin, whereas the heart enzyme is regulated differently (Borensztajn et al. 1972).

At the beginning of balanced refeeding, LPL activity of epididymal fat was increased and was similar to that of the control group. However, the relative and absolute weights of this tissue remained lower throughout refeeding duration. At day 14 of balanced refeeding, the epididymal fat tissue relative weight was increased compared with the value obtained at day 2 of balanced refeeding, but its LPL activity per $\mathrm{g}$ fresh tissue was diminished. LPL activities of heart and gastrocnemius were enhanced with refeeding duration but in contrast with LPL activity of epididymal fat tissue, these activities rose more progressively during balanced refeeding.

A rebound effect was observed only in liver lipolytic activity. This privileged synthesis of liver lipolytic activity during balanced refeeding indicates that lipolytic activity has its own particular modulated expression (transcription, glycosylation, transport and secretion). There is evidence for independent genetic regulation of LPL in different tissues (Ben-Zeev et al. 1983) and post-translational nutritional regulation of these LPL has been proposed (Doolittle et al. 1990).

In conclusion, our data confirm that protein malnutrition involves liver TAG accumulation, with reduced serum and VLDL-TAG and -Apo concentrations, i.e. impaired transport of TAG. LPL activities of the extrahepatic tissues studied were maintained at the values observed at the beginning of protein malnutrition, but when compared with those of control rats, these activities were lower and the lowest activity was found in epididymal fat. On the other hand, hepatic lipolytic activity did not change during protein malnutrition. Therefore, during protein malnutrition, the low VLDL-TAG exported from the liver could be hydrolysed efficiently by tissues despite the low extrahepatic tissue LPL activity. However, though LPL activity is important in determining fatty acid availability to tissues, the substrate concentration is also critical. More direct studies of lipid utilisation are required since determination of lipolytic activities does not provide conclusive information on lipid fuel availability to tissues.

\section{Acknowledgement}

The authors are indebted to Anne Magnet, an English for Specific Purposes linguist at the University of Burgundy, for editing the manuscript.

\section{References}

Agbedana EO (1980) Changes in serum post heparin and tissue lipoprotein lipase activities in protein malnourished rats. Nutrition Reports International 32, 157-165.

Barker DJP (1995) Fetal origins of coronary heart disease. British Medical Journal 311, 544-550.

Barker DJP, Gluckman PD, Godfrey KM, Harding JE, Owens JA \& Robinson JS (1993) Fetal nutrition and cardiovascular disease in adult life. Lancet 341, 938-941.

Ben-Zeev O, Lusis AJ, Laboeuf RC, Nikazy J \& Schotz MC (1983) Evidence for independent genetic regulation of heart and adipose lipoprotein lipase activity. Journal of Biological Chemistry 258, 13632-13640.

Borensztajn J, Samols DR \& Rubenstein AH (1972) Effects of insulin on lipoprotein lipase activity in the rat heart and adipose tissue. American Journal of Physiology 223, 1271-1275.

Brunzell JD (1989) Familial lipoprotein lipase deficiency and other causes of chylomicronemia syndrome. In The Metabolic Basis of Inherited Disease, pp. 1165-1180 [CR Scriver, AL Baudet, WS Sly and D Valle, editors]. New York, NY: Mc Graw Hill.

Council of European Communities (1986) Directives of the Council concerning the animal protection for the use of living animals in scientific investigations. Official Journal of European Communities 86/609, L358, 1-28.

Doolittle MH, Ben-Zeev O, Elovson J, Martin D \& Kirchgessner TG (1990) The response of lipoprotein lipase to feeding and fasting. Journal of Biological Chemistry 265, 4570-4578.

Duncan DB (1955) Multiple range and multiple F-tests. Biometrics 15, 1-42.

Eckel RH (1989) Lipoprotein lipase. A multifunctional enzyme relevant to common metabolic diseases. New England Journal of Medicine 320, 1060-1068.

Eisenberg S (1984) High density lipoprotein metabolism. Journal of Lipid Research 25, 1017-1058.

Faergeman O \& Havel RJ (1975) Metabolism of cholesteryl esters of rat very low density lipoproteins. Journal of Clinical Investigation 55, 1210-1218.

Fidge NH \& Poulis P (1975) Studies on the metabolism of rat serum very low density lipoprotein. Journal of Lipid Research 16, 367-378.

Flores H, Pak N, Macioni A \& Monckeberg F (1970a) Lipid transport in kwashiorkor. British Journal of Nutrition 24, 10051011.

Flores H, Sierralta W \& Monckeberg F (1970b) Triglyceride transport in protein depleted rats. Journal of Nutrition $\mathbf{1 0 0}$, 375-379.

Folch J, Lees M \& Sloane Stanley GH (1957) A simple method 
for the isolation and purification of total lipides from animal tissues. Journal of Biological Chemistry 26, 497-509.

Ginsberg HN (1991) Lipoprotein physiology in nondiabetic and diabetic states. Relationship to atherogenesis. Diabetes Care 14, 839-855.

Goldberg IJ, Scheraldi CA, Yacoub LK, Saxena U \& Bisgaier CL (1990) Lipoprotein apoC-II activation of lipoprotein lipase. Journal of Biological Chemistry 265, 4266-4271.

Hamosh M, Clary TR, Chernick SS \& Scow RD (1970) Lipoprotein lipase activity of adipose and mammary tissue and plasma triglycerides in pregnant and lactating rats. Biochimica et Biophysica Acta 210, 473-482.

Hills MJ \& Mukherjee KD (1988) Assay for triacylglycerollipase: A rapid thin layer chromatographic technique. Journal of Lipid Research 29, 1397-1399.

Ikeda Y, Atsuko T \& Yamamoto A (1989) Purification and characterization of lipoprotein lipase and hepatic triglyceride lipase from human postheparin plasma: Production of monospecific antibody to the individual lipase. Biochimica et Biophysica Acta 1003, 254-269.

Kadowaki H, Patton GM \& Robins SJ (1992) Metabolism of high density lipoprotein lipids by the rat liver: evidence for the participation of hepatic lipase in the uptake of cholesteryl esters. Journal of Lipid Research 33, 1689-1698.

Kuusi T, Kinnunen PKS \& Nikkila EA (1979a) Hepatic endothelial lipase antiserum influences rat plasma low and high density lipoprotein in vivo. FEBS Letters 104, 384-388.

Kuusi T, Nikkita EA, Virtamen J \& Kinnunen PK (1979b) Localization of the heparin-releasable lipase in situ in the rat liver. Biochemistry Journal 181, 245-246.

Lamri MY, Meghelli-Bouchenak M, Boualga A, Belleville J \& Prost J (1995) Rat plasma VLDL composition and concentration and hepatic lipase and lipoprotein lipase activities are impaired during two types of protein malnutrition and unaffected by balanced refeeding. Journal of Nutrition $\mathbf{1 2 5}$, $2425-2434$

Lowry OH, Rosebrough NJ, Farr AL \& Randall RJ (1951) Protein measurement with the Folin phenol reagent. Journal of Biological Chemistry 193, 265-275.

Lunn PG \& Austin S (1983) Difference in nitrogen metabolism between protein deficiency and energy deficient rats with similarly restricted growth rates. Annals of Nutrition and Metabolism 27, 242-251.

Meghelli-Bouchenak M, Belleville J \& Boquillon M (1989a)
Hepatic steatosis and serum very low density lipoproteins during two types of low protein diets followed by a balanced refeeding. Nutrition 5, 321-329.

Meghelli-Bouchenak M, Belleville J, Boquillon M, Scherrer B \& Prost J (1991) Removal rates of rat serum ${ }^{3} \mathrm{H}$-labeled very low lipoproteins after consumption of two different low protein diets. Nutrition Research 11, 265-275.

Meghelli-Bouchenak M, Boquillon M \& Belleville J (1989b) Serum lipoproteins composition and amount during the consumption of different low protein diets followed by a balanced diet. Nutrition Reports International 39, 323-343.

Meghelli-Bouchenak M, Boquillon M \& Belleville J (1987) Time course of changes in rat serum apolipoproteins during the consumption of different low protein diets followed by a balanced diet. Journal of Nutrition 117, 641-649.

Mohamed-Benkada K, Belleville J \& Prost J (1993) Comparative changes between pancreas and pancreatic juice digestive enzyme contents during nutritional rehabilitation following severe protein malnutrition in the rat. British Journal of Nutrition 69, 83-90.

Okabe T, Yorifuji H, Murase T \& Takaku F (1984) Pulmonary macrophage: a major source of lipoprotein lipase in the lung. Biochemical and Biophysical Research Communications 125, 273-278.

Olivecrona T \& Bengtsson-Olivecrona G (1990) Lipoprotein lipase and hepatic lipase. Current Opinion in Lipidology $\mathbf{1}$, 222-230.

Onitri AC \& Boyo AE (1975) Serum lipids and lipoproteins in children with kwashiorkor. British Medical Journal 5984, 630636.

Seakins AL \& Waterlow JC (1972) Effect of a low protein diet in incorporation of amino acids into rat serum lipoproteins. Biochemistry Journal 129, 793-795.

Soteriou A \& Cryer A (1993) Purification and characterization of lipoprotein lipase from the white adipose, skeletal muscle, cardiac muscle, mammary gland and lung tissues of the rat. International Journal of Biochemistry 25, 1483-1490.

Truswell AS, Hansen JD, Watson CE \& Wannenburg P (1969) Relation of serum lipids and lipoprotein to fatty liver in kwashiorkor. American Journal of Clinical Nutrition 22, 568576.

Waterlow JC, (1975) Amount and rate of disappearance of liver fat in malnourished infants in Jamaica. American Journal of Clinical Nutrition 2, 1330-1336. 